\title{
Effect of genetic line on energy and nitrogen metabolism during late gestation in twin-pregnant ewes fed restrictedly*
}

\author{
A. Kiani ${ }^{1}$, A. Chwalibog, M.O. Nielsen and A.H. Tauson \\ Department of Animal and Veterinary Basic Sciences, \\ The Royal Veterinary and Agricultural University \\ Gronnegaardsvej 7, DK-1870 Ferderiksberg C, Denmark
}

\begin{abstract}
Nitrogen and energy metabolism were measured in balance and respiration experiments performed seven weeks before expected lambing in twenty twin-pregnant ewes from two genetic lines: high average daily gain (Gain) and slaughter quality (Lean). Ewes were grouped according to liveweight (LW): heavier (Heavy) and lighter (Light) than the average for the genetic line. All animals were fed restrictedly, about $70 \%$ of their energy requirements.

Selection for slaughter quality rather than high daily gain increased apparent crude protein digestibility ( 77.9 vs $81.1 \%$ for Gain and Lean, respectively, $\mathrm{P}<0.05$ ), but neither genetic line nor LW affected other parameters of quantitative nitrogen and energy metabolism.
\end{abstract}

KEY WORDS: under-nutrition, digestibility, heat production, nitrogen balance, energy balance

\section{INTRODUCTION}

In order to improve performance and slaughter quality of sheep several breeding programmes have been carried out (Givens and Moss, 1994; Ranilla et al., 1998). In Denmark we have established 2 genetic lines of Shropshire ewes by mating for several generations either to a ram with high genetic potential for daily weight gain (Gain) or high slaughter quality (high muscle and low fat content, Lean). However, the effects of such a selection on quantitative nitrogen and energy metabolism have not been investigated. The objective of the present study was to investigate effects of genetic line (GL) on nitrogen and energy metabolism during late gestation of twin-pregnant ewes fed a restricted diet.

\footnotetext{
${ }^{*}$ A. Kiani holds a PhD Scholarship from the Ministry of Science, Research and Technology, Iran

${ }^{1}$ Corresponding author: e-mail: alk@kvl.dk
} 


\section{MATERIAL AND METHODS}

Twenty twin-pregnant ewes from two GL's selected for high average daily gain (Gain) and slaughter quality (Lean) were grouped according their liveweight $(\mathrm{LW})$ : heavier (Heavy) $(\mathrm{n}=10)$ and lighter (Light) $(\mathrm{n}=10)$ than genetic line average. Ewes were fed $70 \%$ of NRC requirements for energy (NRC, 1985). The experimental period lasted 14 days; animals were adapted to the diet for one week, whereafter they were placed in metabolic cages. Balance experiments lasted 7 days, including 2 days of adaptation, followed by a 5 day balance period with collection of faeces, urine and feed residues. On the $3^{\text {rd }}$ day of the balance period, a $22 \mathrm{~h}$ respiration measurement was carried out. Animals had free access to drinking water and feed was offered in two equal amounts at 10.00 and $15.00 \mathrm{~h}$. Liveweights were recorded at the beginning and at the end of the experiment. Nitrogen content in feed, faeces and urine was determined by the Kjeldahl method using the TecatorKjeltec system.

Concentrations of gross energy (GE) in feed and faeces was determined by adiabatic bomb calorimetry (system C700, IKA Analysentechnic $\mathrm{GmbH}$, Heitersheim, Germany). The energy concentration of urine was calculated from the $\mathrm{N}$ content in urine (Hoffmann and Klein, 1980). An open-air-circuit respiration unit (Chwalibog et al., 2004) was used for measurements of $\mathrm{O}_{2}$ consumption and $\mathrm{CO}_{2}$ and $\mathrm{CH}_{4}$ production. Heat production was calculated from gaseous exchange and urinary nitrogen excretion by Brower's equation (Brouwer, 1965). Energy retention was calculated by subtracting energy loss via faeces, urine, methane, and heat from GE input.

The experiment was carried out as a completely random factorial design with two factors, genetic line and body weight class. The general linear models procedure (GLM) was applied for analysis of variances (SAS, 1990).

\section{RESULTS}

As expected there was a significant difference $(\mathrm{P}<0.05)$ in body weight between Gain $(78.8 \mathrm{~kg}$ ) and Lean $(70.9 \mathrm{~kg})$, however, the feed intake was not different (Table 1).

Genetic line (GL) and LW did not affect digestibility of dry matter and energy, but apparent protein digestibility was significantly higher in ewes from the Lean compared to the Gain line ( 81.1 vs $77.9 \%$; $\mathrm{P}<0.05)$. No significant effects or interactions between LW and GL were observed regarding heat production, nitrogen and energy balances, the latter being negative in all measurements, indicating mobilization of body fat. 


\section{DISCUSSION}

In the present study the only difference between GL's with respect to quantitative protein and energy metabolism was observed for digestibility of the protein fraction. Selection for high muscle content in the cascass was reflected in a higher capacity for protein digestibility. However, overall nitrogen balance was not affected.

Neither GL nor LW affected dry matter (DMD) and energy digestibility. This result is in accordance with the finding of Ranilla et al. (1998), who reported no breed differences between Churra and Merino sheep in DMD when fed a goodquality forage at a low level of intake. Furthermore, for sheep fed ad libitum genetic origin had no effect on DMD and organic matter digestibility (OMD) (Molina et al., 2001). However, Givens and Moss (1994) demonstrated that Cheviot sheep (mean body weight $58.4 \mathrm{~kg}$ ) had higher DMD and OMD than Suffolk $\times$ Mule sheep (mean body weight $69.7 \mathrm{~kg}$ ).

Although, in the present investigation, neither heat production, energy balance, nor nitrogen balance were significantly different, a large in-between animal variation might have biased the results and more data will be necessary to verify the conclusion.

Table 1. Feed intake, digestibility, energy and nitrogen metabolism in two genetic lines of twinpregnant ewes

\begin{tabular}{|c|c|c|c|c|c|c|c|}
\hline \multirow{3}{*}{$\begin{array}{l}\text { Genetic line (GL) } \\
\text { Liveweight }\end{array}$} & \multicolumn{2}{|c|}{ Gain } & \multicolumn{2}{|c|}{ Lean } & \multirow{3}{*}{ SEM } & \multirow{2}{*}{\multicolumn{2}{|c|}{ Effects }} \\
\hline & \multirow{2}{*}{$\begin{array}{l}\text { light } \\
\mathrm{n}=4\end{array}$} & \multirow{2}{*}{$\begin{array}{c}\text { heavy } \\
n=6\end{array}$} & \multirow{2}{*}{$\begin{array}{l}\text { light } \\
\mathrm{n}=6\end{array}$} & \multirow{2}{*}{$\begin{array}{c}\text { heavy } \\
n=4\end{array}$} & & & \\
\hline & & & & & & GL & LW \\
\hline \multicolumn{8}{|l|}{ Intake and digestibility } \\
\hline dry matter (DM) intake, $\mathrm{g} / \mathrm{d}$ & $848^{\mathrm{al}}$ & $959^{\mathrm{b}}$ & $811^{\mathrm{a}}$ & $917^{\mathrm{b}}$ & 68 & ns & $* *$ \\
\hline DM digestibility, $\%$ & 67.5 & 65.8 & 69.6 & 66.0 & 3.9 & ns & ns \\
\hline energy digestibility, $\%$ & 65.9 & 64.4 & 68.8 & 64.8 & 4.1 & ns & ns \\
\hline protein digestibility $\%$ & $75.2^{\mathrm{a}}$ & $79.7^{\mathrm{b}}$ & $81.0^{\mathrm{b}}$ & $81.3^{\mathrm{b}}$ & 3.6 & $*$ & ns \\
\hline \multicolumn{8}{|l|}{ Energy metabolism } \\
\hline digestible energy, $\mathrm{MJ} / \mathrm{d}$ & 9.30 & 10.30 & 9.30 & 9.92 & 1.14 & ns & ns \\
\hline metabolizable energy, $\mathrm{MJ} / \mathrm{d}$ & 6.98 & 7.85 & 7.10 & 7.64 & 0.92 & ns & ns \\
\hline heat production, $\mathrm{MJ} / \mathrm{d}$ & 8.66 & 10.2 & 8.43 & 9.59 & 1.79 & ns & ns \\
\hline heat production, $\mathrm{kJ} / \mathrm{kg}^{0.75} \cdot \mathrm{d}$ & 347 & 374 & 360 & 370 & 72 & ns & ns \\
\hline energy balance, $\mathrm{MJ} / \mathrm{d}$ & -1.68 & -2.35 & -1.33 & -1.95 & 1.92 & ns & ns \\
\hline \multicolumn{8}{|l|}{ Nitrogen metabolism, g/d } \\
\hline intake & $14.45^{\mathrm{a}}$ & $16.30^{\mathrm{b}}$ & $13.78^{\mathrm{a}}$ & $15.50^{\mathrm{b}}$ & 0.99 & ns & $* *$ \\
\hline digested & $10.86^{\mathrm{a}}$ & $13.03^{\mathrm{b}}$ & $11.19^{\mathrm{a}}$ & $12.66^{\mathrm{b}}$ & 1.14 & ns & $* *$ \\
\hline nitrogen balance & -0.45 & 2.13 & 0.95 & 2.10 & 2.48 & ns & ns \\
\hline
\end{tabular}

ns - not statistically significant

$* \mathrm{P}<0.05 ; * * \mathrm{P}<0.01$

${ }^{1}$ means with same letter in the rows are not significantly different $(\mathrm{P}>0.05)$ 


\section{CONCLUSIONS}

In conclusion, no significant differences were found between the genetic lines regarding energy and nitrogen metabolism except for a higher protein digestibility in the line selected for slaughter quality. This was however not reflected in increased capacity for protein deposition, but a large in-between animal variation may have masked such an effect.

\section{REFERENCES}

Brouwer E., 1965. Report of sub-committee on onstants and factors. In: K.L. Blaxter (Editor). Energy Metabolism of Farm Animals. EAAP Publication, London

Chwalibog A., Tauson A.H., Thorbek G., 2004. Energy metabolism and substrate oxidation in pigs during feeding, starvation and re-feeding. J. Anim. Physiol. Anim. Nutr. 88, 101-112

Givens D.I., Moss A.R., 1994. Effect of breed, age and bodyweight of sheep on the measurement of apparent digestibility of dried grass. Anim. Feed Sci. Tech. 46, 155-162

Hoffmann L., Klein M., 1980. The dependence of urine energy on the carbon and nitrogen-content of the urine of cattle, sheep, pigs and rats. Arch. Anim. Nutr. 30, 743-750

Molina E., Ferret A., Caja G., Calsamiglia S., Such X., Gasa J., 2001. Comparison of voluntary food intake, apparent digestibility, digesta kinetics and digestive tract content in Manchega and Lacaune dairy sheep in late pregnancy and early and mid lactation. Anim. Sci. 72, 209-221

NRC, 1985. Nutrient Requirements of Sheep. 6th Edition. National Academy Press, Washington, $\mathrm{DC}$

Ranilla M.J., Lopez S., Giraldez F.J., Valdes C., Carro M.D., 1998. Comparative digestibility and digesta flow kinetics in two breeds of sheep. Anim. Sci. 66, 389-396

SAS, 1990. SAS Procedures Guide. 3rd Edition. SAS Inst. Inc, Cary, NC 